\title{
DIVERSITY, ECOLOGY AND TAXONOMY OF THE POLYCHAETES (ANNELIDA: POLYCHAETA) IN HONOR OF PROF. ERNST EHLERS.
}

\section{Motivation of the volume}

Given the current impact generated by human activities, biodiversity studies along the Chilean Pacific coast are a matter of high interest to scientists and decision makers. Actually, biodiversity is an important tool for the design, conservation and management of marine protected areas (CONAMA 2006; Salmo et al. 2000) as well as it is required for environmental impact evaluation and baseline studies under the environmental Chilean regulation (Buchmann et al. 2009).

Actually, the marine Magellan ecosystem appears to be suitable for aquaculture. In fact, the Magellan area is under high pressure of a newly implemented salmon farming industry (Buchmann et al. 2006). In this sense, benthic diversity studies should have a high priority, because information about actual diversity patterns is urgently needed as baseline data for the recognition of future changes. However, the calculation of diversity in marine benthic communities is highly complex, because many supplies are required. We need, for example, to develop high ecological information level and a well-known species inventory of the area. In the moment we lack in the Magellan area large-scale studies to update environmental and taxonomical information.

In this context, polychaetes with more than 300 described species (Montiel et al. 2005) are the second most diverse invertebrate group in the Magellan benthic realm ( $c f$. Häussermann \& Försterra 2009; Montiel et al. 2005; Montiel \& Rozbaczylo 2009). Paradoxically, scarce studies on taxonomy and ecology of this invertebrate group have been realized in the Magellan area up to now, thus underlining that such studies on polychaetes are urgently needed.

Under this scenario, we would like to dedicate the second 2010 number of the Anales del Instituto de la Patagonia (Volume 38, number 2) to Prof. Ernst Ehlers (1835-1925). He worked worldwide on polychaete taxonomy and he was the first annelidologist studying intensively the Magellan polychaete fauna. In his monographs "Polychaeten Hamburger
Magelhaensische Sammelreise (149 pag., 9 plates, Hamburg, 1897)" and "Die Polychaeten des Magellanischen und Chilenischen Strandes, (232 pag. 25 plates, Berlin 1901)" he described 36 new species from 50 Magellan sampling sites. Nowadays, these monographs are considered an important contribution to the actual knowledge of the polychaete diversity and zoogeography in the Magellan area.

Aim

The aim of this volume is to contribute to the knowledge of polychaete biodiversity in the Magellan marine system by publishing some new ecological (new distribution range of species and new studies areas) and taxonomical information (new records and taxonomical review) from areas not previous study to this group.

Drs. Américo Montiel \& Carlos Ríos Instituto de la Patagonia Universidad de Magallanes

Contribution to the volume in alphabetic order:

Bremec C., V. Souto \& G. Genzano 2010. POLYCHAETE ASSEMBLAGES IN SW ATLANTIC: RESULTS OF "SHINKAI MARU" IV, V, X AND XI (1978-1979) CRUISES IN PATAGONIA AND BUENOS AIRES.

Cañete J., M. Astorga, M. Santana \& M. Palacios 2010. ABUNDANCIA Y DISTRIBUCIÓN ESPACIAL DE SCOLECOLEPIDES UNCINATUS BLAKE, 1983 (POLYCHAETA: SPIONIDAE) Y CARACTERISTICAS SEDIMETOLOGICAS BAHÍA LOMAS, TIERRA DEL FUEGO, CHILE.

Hüne M. \& G. Rivera 2010. CONTRIBUCIÓN DE POLIQUETOS (ANNELIDA: POLYCHAETA) EN LA DIETA DE TRES ESPECIES DE NOTOTÉNIDOS (PERCIFORMES; NOTOTHENIOIDEI) EN LA REGIÓN DE MAGALLANES. 
Ortiz P. \& E. Quiroga 2010. NUEVOS REGISTROS Y DISTRIBUCIÓN DE POLIQUETOS (ANNELIDA, POLYCHAETA) BENTÓNICOS SUBMAREALESDE FONDOSBLANDOSEN LA REGIÓN DE AISÉN, CHILE: FAMILIAS PARAONIDAE Y SPIONIDAE.

Quiroga E. \& L. Levin 2010. EUNICE (POLYCHAETA, EUNICIDAE) FROM ACTIVE AND PASSIVE COLD SEEP SITES IN CENTRAL AND SOUTHERN CHILE $\left(36^{\circ}-46^{\circ}\right)$.

Soto E. H. \& G. L. J Paterson 2010. POLIQUETOS BENTÓNICOS INTERMAREALES Y SUBLITORALES DE LA REGIÓN DE AISÉN, CHILE.

Tovar-Hernández M. 2010. TAXONOMIC UPDATE OF THE SABELLIDS (POLYCHAETA: SABELLIDAE) FROM CHILE AND TAXA ESTABLISHED BY PROF. ERNST EHLERS, WITH A KEY TO GENERA OF SABELLINAE.

\section{ACKNOWLEDGEMENT}

We gratefully acknowledge the critical reviews of the scientific publications in this volume by 11 referees (listed below). Without their help this volume would not have been published.

\section{LIST OF REFEREES OF THIS VOLUME}

Dr. Alice Turner (Universidad Austral, Chile).

Dr. Brigitte Ebbe (Senckenberg am Meer, German Centre for Marine Biodiversity Research, Alemania).

Dr. Emma Newcombe (Centro de Estudio del Cuaternario Fuego Patagónico y Antártica, Chile)

MSc. Claudia Andrade (Alfred Wegener Institute, Alemania).

MSc. Beatriz Yañes (Universidad Nacional Autónoma de México, México).

Dr. Dieter Gerdes (Alfred Wegener Institute, Alemania).

Dr. Carlos Ríos (Universidad de Magallanes, Chile).

Dr. Eduardo Quiroga (Pontificia Universidad de Valparaíso, Chile).
Dr. Cristian Aldea (Centro de Estudio del Cuaternario Fuego Patagónico y Antártica, Chile).

Dr. Roger Sepulveda (Universidad Austral, Chile). Prof. Vicente Pérez (Universidad de Magallanes, Chile).

\section{LITERATURA}

Buschmann, A., H. Riquelme, V.A. Hernández-González, M.C. Varela, D. Jiménez, J. Henríquez, L.A. Vergara, P.A. Guíñez \& R., Filún 2006. A review of the impacts of salmon farming on marine coastal ecosystems in the southeast Pacific. ICES Journal of Marine Science 63: 1338-1345.

Buschmann, A., F. Cabello, K. Young, J. Carvajal, D. A. Varela \& L. Henríquez 2009. Salmon aquaculture and coastal ecosystem health in Chile: Analysis of regulations, environmental impacts and bioremediation systems. Ocean \& Coastal Management 52(5): 243-249.

CONAMA 2006. Conservación de la biodiversidad de importancia a lo largo de la costa chilena: Áreas marinas y costeras protegidas de múltiples usos. Ocho Libros Editores Ltda. Providencia Santiago: $182 \mathrm{pp}$.

Häussermann V. \& G. Försterra 2009 Fauna Marina Bentónica de la Patagonia. Nature in Focus Santiago, Chile. 1000 pp.

Montiel A., D. Gerdes \& W. Arntz 2005. Distribution patterns of shallow waters polychaetes in the Magellan region: a zoogeographical and ecological synopsis. Scientia Marina 69 (suppl. 2): 123-133.

Montiel A., \& N. Rozbaczylo 2009. Poliquetos. En Häussermann \& Försterra (Eds.) Fauna Marina Bentónica de la Patagonia. Nature in Focus, Santiago, Chile. 543-581 pp.

Salmo S.G., R.A. Turion, M.A. Juinio-Meñez \& P.M. Aliño 2000. Establishment and Implementation of the Balingasay Marine Protected Area: A Community-Based Approach. Science Diliman 12(2): 121-128. 